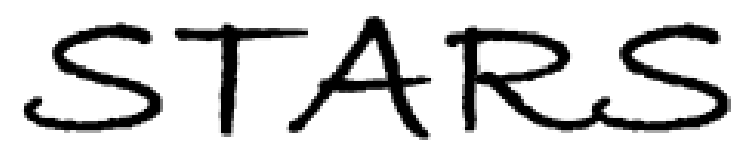

University of Central Florida

STARS

$1-1-2000$

\title{
Scanning probe metrology in the presence of surface charge
}

\author{
J. E. Griffith \\ E. M. Kneedler \\ S. Ningen \\ A. Berghaus \\ C. E. Bryson III
}

See next page for additional authors

Find similar works at: https://stars.library.ucf.edu/facultybib2000 University of Central Florida Libraries http://library.ucf.edu

This Article; Proceedings Paper is brought to you for free and open access by the Faculty Bibliography at STARS. It has been accepted for inclusion in Faculty Bibliography 2000s by an authorized administrator of STARS. For more information, please contact STARS@ucf.edu.

\section{Recommended Citation}

Griffith, J. E.; Kneedler, E. M.; Ningen, S.; Berghaus, A.; Bryson, C. E. III; Pau, S.; Houge, E.; and Shofner, T., "Scanning probe metrology in the presence of surface charge" (2000). Faculty Bibliography 2000s. 7904. https://stars.library.ucf.edu/facultybib2000/7904

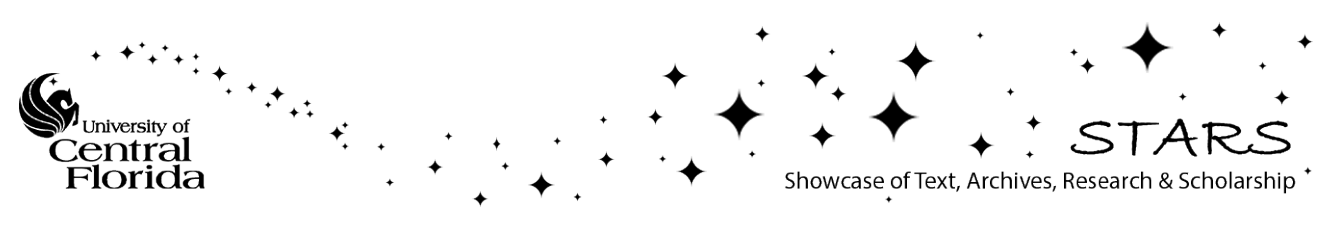




\section{Authors}

J. E. Griffith, E. M. Kneedler, S. Ningen, A. Berghaus, C. E. Bryson III, S. Pau, E. Houge, and T. Shofner 


\section{Secondary ion mass spectrometry characterization of the diffusion properties of 17 elements implanted into silicon}

H. Francois-Saint-Cyr, E. Anoshkina, F. Stevie, L. Chow, K. Richardson, and D. Zhou

Citation: Journal of Vacuum Science \& Technology B: Microelectronics and Nanometer Structures Processing, Measurement, and Phenomena 19, 1769 (2001); doi: 10.1116/1.1396638

View online: https://doi.org/10.1116/1.1396638

View Table of Contents: https://avs.scitation.org/toc/jvn/19/5

Published by the American Institute of Physics

\section{ARTICLES YOU MAY BE INTERESTED IN}

Room-temperature operation of a titanium supersaturated silicon-based infrared photodetector Applied Physics Letters 104, 211105 (2014); https://doi.org/10.1063/1.4879851

Mechanisms of boron diffusion in silicon and germanium Journal of Applied Physics 113, 031101 (2013); https://doi.org/10.1063/1.4763353

Mechanisms of transition-metal gettering in silicon Journal of Applied Physics 88, 3795 (2000); https://doi.org/10.1063/1.1289273

Solubility and Diffusivity of Gold, Iron, and Copper in Silicon Journal of Applied Physics 27, 1560 (1956); https://doi.org/10.1063/1.1722310

Characterization of silver-related deep levels in silicon Journal of Applied Physics 62, 2853 (1987); https://doi.org/10.1063/1.339425

Atomic scale origins of sub-band gap optical absorption in gold-hyperdoped silicon AIP Advances 8, 055014 (2018); https://doi.org/10.1063/1.5023110 


\title{
Secondary ion mass spectrometry characterization of the diffusion properties of 17 elements implanted into silicon
}

\author{
H. Francois-Saint-Cyr \\ Advanced Materials Processing and Analysis Center, Department of Mechanical, Materials, and Aerospace \\ Engineering, School of Optics, University of Central Florida, Orlando, Florida 32816 \\ E. Anoshkina \\ Advanced Materials Processing and Analysis Center, Department of Mechanical, Materials, and Aerospace \\ Engineering, University of Central Florida, Orlando, Florida 32816 \\ F. Stevie ${ }^{\text {a) }}$ \\ Cirent Semiconductor (Agere Systems), 9333 South John Young Parkway, Orlando, Florida 32819 \\ L. Chow \\ Advanced Materials Processing and Analysis Center, Department of Physics, University of Central Florida, \\ Orlando, Florida 32816 \\ K. Richardson \\ Advanced Materials Processing and Analysis Center, Department of Physics, Department of Chemistry, \\ University of Central Florida, Orlando, Florida 32816 \\ D. Zhou \\ Advanced Materials Processing and Analysis Center, Department of Mechanical, Materials, and Aerospace \\ Engineering, University of Central Florida, Orlando, Florida 32816
}

(Received 26 October 1999; accepted 2 July 2001)

\begin{abstract}
A systematic investigation of the diffusion of $\mathrm{Be}, \mathrm{B}, \mathrm{Na}, \mathrm{Mg}, \mathrm{Cl}, \mathrm{K}, \mathrm{Ca}, \mathrm{Ti}, \mathrm{V}, \mathrm{Cr}, \mathrm{Mn}, \mathrm{Fe}, \mathrm{Ni}, \mathrm{Zn}$, $\mathrm{Ge}, \mathrm{Rb}$, and $\mathrm{Mo}$ in silicon has been carried out. The elements were implanted into silicon wafers as low dose impurities, and then postheat treatments of the ion-implanted samples were conducted at different temperatures for a specific time. Following the anneals, the depth profiles were obtained by secondary ion mass spectrometry analyses. A wide range of diffusion behavior has been observed for these elements. Based on differences in the depth profiles the diffusion mechanism was identified where possible. (C) 2001 American Vacuum Society. [DOI: 10.1116/1.1396638]
\end{abstract}

\section{INTRODUCTION}

The modern semiconductor industry is based on integrated circuits formed from silicon doped with $n$ - and $p$-type dopants. Diffusion and ion implantation are the two main techniques for introducing different dopants into Si wafers. Since the performance of a device depends critically on dopant distribution, diffusion plays a major role in transistor fabrication. Semiconductor failures are often caused by the diffusion of metallic elements (or contaminants) introduced during device processing. Therefore, a better understanding of diffusion phenomena of metallic elements in silicon is valuable for quality control and failure analysis.

Intrinsic diffusion of metallic impurities in silicon has been under study since the early 1960s. ${ }^{1-4}$ Most of the data were obtained at that time by annealing a deposited layer on the silicon surface (see Table I). It was noted that, for most elements, the Arrhenius expression is obeyed, indicating thermally activated diffusion. The data compiled show that diffusion is either interstitial or substitutional and there is a wide range of diffusivity for different impurities (over ten orders of magnitude at a given temperature.)

Since the early 1970s, ion implantation ${ }^{5}$ has been gradu-

\footnotetext{
a) Author to whom correspondence should be addressed: electronic mail: stevie@agere.com
}

ally developed into a standard tool to introduce dopants into silicon. Ion implantation generates additional point defects inside Si that further complicate the impurity diffusion phenomena. It is recognized that diffusion of the implanted species during annealing can be affected by the defects generated during the implantation process, in the extreme case causing the formation of an amorphous layer, and by the charge state of the implants. The diffusion behavior of common dopants implanted into Si such as $\mathrm{B},{ }^{6} \mathrm{As}^{7}{ }^{7} \mathrm{Sb}^{8}$ and $\mathrm{P}^{9}$ have been well characterized. However, diffusion data on contaminant elements implanted into $\mathrm{Si}$ are not generally available. Studies have been made of implanted $\mathrm{Fe}$ in InGaAsP ${ }^{10}$ and $\mathrm{Fe}$ and $\mathrm{Co}$ in InP. ${ }^{11}$ In this article, we examine the diffusion behavior of 17 elements, including $\mathrm{Be}, \mathrm{B}$, $\mathrm{Na}, \mathrm{Mg}, \mathrm{Cl}, \mathrm{K}, \mathrm{Ca}, \mathrm{Ti}, \mathrm{V}, \mathrm{Cr}, \mathrm{Mn}, \mathrm{Fe}, \mathrm{Ni}, \mathrm{Zn}, \mathrm{Ge}, \mathrm{Rb}$, and Mo, implanted into Si.

\section{EXPERIMENTAL CONDITIONS}

Isotopes of the 17 elements were introduced into (100) single-crystalline silicon by ion implantation at room temperature. ${ }^{51} \mathrm{~V}$ was implanted into both silicon and a $0.5 \mu \mathrm{m}$ polysilicon layer on silicon substrate. The implantation energies and doses ranged from 50 to $180 \mathrm{keV}$ and $7.5 \mathrm{E} 13$ to $1.1 \mathrm{E} 15$ atoms $/ \mathrm{cm}^{2}$, respectively. The implanted doses for elements with atomic number greater than $\mathrm{Si}$ were determined 
TABLE I. Diffusion properties of elements in silicon.

\begin{tabular}{|c|c|c|c|c|c|}
\hline Element & $\begin{array}{l}\text { Ionic } \\
\text { radius } \\
(\mathrm{nm})\end{array}$ & $\begin{array}{l}\text { Crystal } \\
\text { structure }\end{array}$ & $\begin{array}{l}\text { Diffusion } \\
\text { mechanism }\end{array}$ & $\begin{array}{c}\text { Diffusivity } \\
\text { at } 1000^{\circ} \mathrm{C} \\
\left(\mathrm{cm}^{2} / \mathrm{s}\right)\end{array}$ & $\begin{array}{c}\text { Solubility } \\
\text { at } 1000^{\circ} \mathrm{C} \\
\left(\text { atoms } / \mathrm{cm}^{-3}\right)\end{array}$ \\
\hline $\mathrm{Be}$ & 0.034 & hcp & I & & \\
\hline B & 0.02 & Rhombohedral & $\mathrm{S}$ & $1.0 \times 10^{-14 a}$ & $10^{21 b}$ \\
\hline $\mathrm{Na}$ & 0.098 & bcc & $\mathrm{I}$ & $1.6 \times 10^{-6 a}$ & $\sim 10^{18 \mathrm{a}}$ \\
\hline $\mathrm{Mg}$ & 0.078 & hcp & I & & \\
\hline $\mathrm{Cl}$ & 0.181 & & I & & \\
\hline $\mathrm{K}$ & 0.133 & bcc & $\mathrm{I}$ & $4 \times 10^{-7 a}$ & $\sim 10^{18 \mathrm{a}}$ \\
\hline $\mathrm{Ca}$ & 0.106 & fcc & I & & \\
\hline $\mathrm{Ti}$ & 0.076 & hcp & $\mathrm{I}$ & $6 \times 10^{-11 \mathrm{c} *}$ & $7 \times 10^{12 a}$ \\
\hline V & 0.065 & bcc & $\mathrm{I}$ & $\sim 10^{-7}$ & \\
\hline $\mathrm{Cr}$ & 0.064 & bcc & I & $2.1 \times 10^{-6 \mathrm{~d} *}$ & $3 \times 10^{14 a}$ \\
\hline Mn & 0.091 & Cubic & I & $2 \times 10^{-6 b}$ & $3 \times 10^{16 b}$ \\
\hline $\mathrm{Fe}$ & 0.087 & bcc & $\mathrm{I}$ & $2.2 \times 10^{-6 a}$ & $3 \times 10^{16 b}$ \\
\hline $\mathrm{Ni}$ & 0.078 & fcc & $\mathrm{I} / \mathrm{S}$ & $2.8 \times 10^{-9 a}$ & $5 \times 10^{17 b}$ \\
\hline $\mathrm{Zn}$ & 0.083 & hcp & $\mathrm{I} / \mathrm{S}$ & $2.9 \times 10^{-7 a}$ & $6 \times 10^{16 b}$ \\
\hline $\mathrm{Ge}$ & 0.044 & Diamond & $\mathrm{S}$ & $7.4 \times 10^{-16 a}$ & \\
\hline $\mathrm{Rb}$ & 0.149 & bcc & I & & \\
\hline Mo & 0.068 & bcc & & & \\
\hline
\end{tabular}

I-Interstitial.

S-Substitutional.

${ }^{a}$ W. E. Beadle, J. C. C. Tsai, and R. D. Plummer, Quick Reference Manual for Silicon Integrated Circuit Technology (Wiley, New York, 1985).

${ }^{\mathrm{b}}$ F. Shimura, Semiconductor Silicon Crystal Technology (Academic, San Diego, 1989).

${ }^{c}$ V. P. Boldyrew, F. I. Prokovskii, S. G. Romanovskaro, A. V. Tkach, and I. E. Shimanovich, Sov. Phys. Semicond. 11, 709 (1977).

${ }^{\mathrm{d}}$ W. Warker, K. Roy, and K. Hesse, Mater. Res. Bull. 9, 971 (1977).

$* 1100^{\circ} \mathrm{C}$.

using Rutherford backscattering spectroscopy. The ionimplanted samples were annealed at 300, 500, 700, 900, and 1000 (or 1100 ) ${ }^{\circ} \mathrm{C}$. The heat treatments were carried out in a Lindberg furnace with a long quartz tube. Once the desired temperature was reached, the quartz tube with the samples was placed into the center of the furnace. The annealing temperature was accurately controlled (nominally $\pm 1{ }^{\circ} \mathrm{C}$ ). During the annealing process, a constant flow of high purity (99.999\%) Ar gas was maintained through the quartz tube. The time of annealing was $30 \mathrm{~min}$ for each sample. After annealing, the quartz tube was moved out of the furnace and the samples were cooled to room temperature in an Ar environment.

Secondary ion mass spectrometry (SIMS) was employed as the primary method of analysis because of good sensitivity and depth resolution. SIMS analyses were carried out with a CAMECA IMS-3f using $150 \mathrm{nA}$ (measured using improved Faraday cup and checked by sputtering rate and primary current comparison with a CAMECA IMS-6f). $\mathrm{O}_{2}^{+}$primary beam at a source potential of $10 \mathrm{kV}$, an impact energy of $5.5 \mathrm{keV}$, and an impact angle of $40^{\circ}$ from normal. ${ }^{12}$ The focused primary beam was rastered over a $200 \mu \mathrm{m} \times 200$ $\mu \mathrm{m}$ area, with detection of ions from an area of $60 \mu \mathrm{m}$ diameter at the center of the raster. The sputtering rate was approximately $0.5 \mathrm{~nm} / \mathrm{s}$. A silicon matrix signal, typically ${ }^{28} \mathrm{Si}^{2+}$, was monitored to ensure a uniform sputtering rate. The depth scale was established for each profile by measuring the crater depth with a stylus profilometer (Sloan Dektak

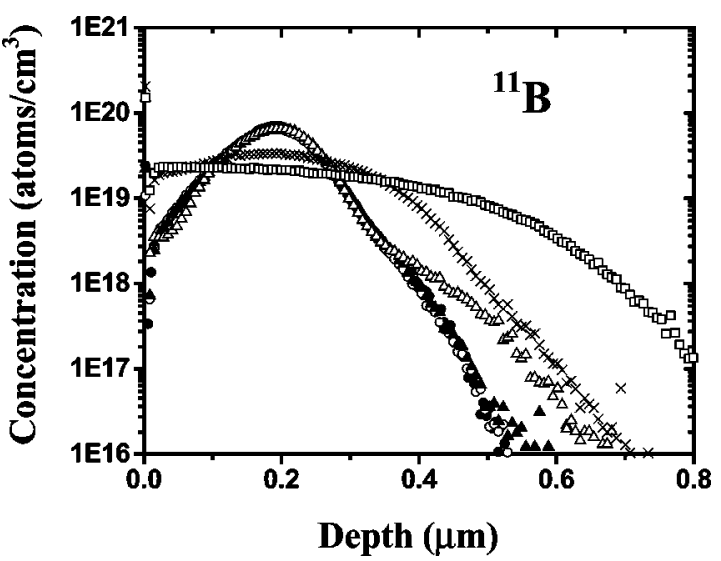

FIG. 1. SIMS depth profiles of ${ }^{11} \mathrm{~B}\left(50 \mathrm{keV}, 1 \mathrm{E} 15\right.$ atoms $\left./ \mathrm{cm}^{2}\right)[\bullet$ as implanted, $\bigcirc$ annealed $\left.300^{\circ} \mathrm{C}, \boldsymbol{\Delta} 500^{\circ} \mathrm{C}, \triangle 700^{\circ} \mathrm{C}, \times 900^{\circ} \mathrm{C}, \square 1000^{\circ} \mathrm{C}\right]$.

IIA). The concentration scales were determined from the known implant doses of the as-implanted samples and the measured erosion rate.

\section{RESULTS AND DISCUSSION}

The diffusion behavior of the 17 elements in silicon may be categorized into five groups. Since the diffusion behavior of implanted boron in silicon has been extensively studied, ${ }^{6}$ it has been used as a control element (category 1). Figure 1 shows SIMS depth profiles of boron in the as-implanted and annealed samples, indicating that there is no diffusion up to

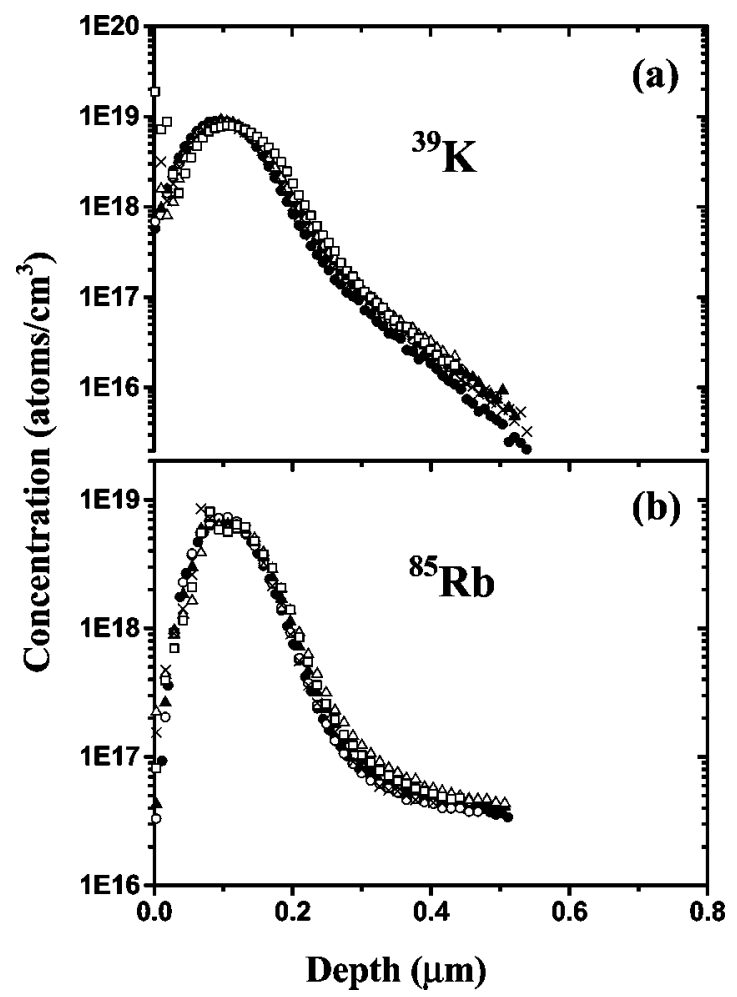

FIG. 2. SIMS depth profiles of (a) ${ }^{39} \mathrm{~K}\left(100 \mathrm{keV}, 1 \mathrm{E} 14 \mathrm{atoms} / \mathrm{cm}^{2}\right)$ and (b) ${ }^{85} \mathrm{Rb}\left(180 \mathrm{keV}, 7.5 \mathrm{E} 13\right.$ atoms $\left./ \mathrm{cm}^{2}\right)\left[\bullet\right.$ as implanted, $\bigcirc$ annealed $300{ }^{\circ} \mathrm{C}, \boldsymbol{\Lambda}$ $500{ }^{\circ} \mathrm{C}, \triangle 700^{\circ} \mathrm{C}, \times 900{ }^{\circ} \mathrm{C}, \square 1100^{\circ} \mathrm{C}$ for $\mathrm{K}$ and $1000^{\circ} \mathrm{C}$ for $\left.\mathrm{Rb}\right]$. 


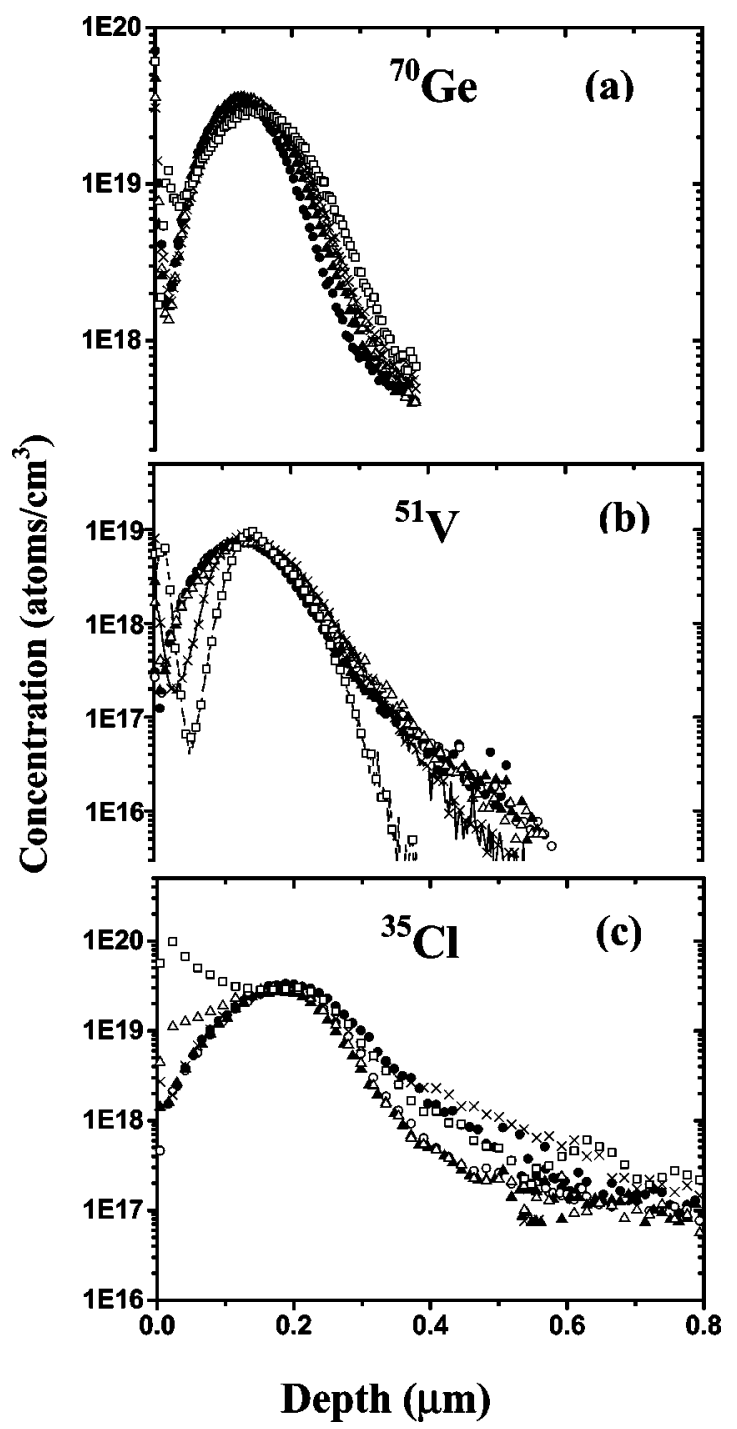

FIG. 3. SIMS depth profiles of (a) ${ }^{70} \mathrm{Ge}\left(180 \mathrm{keV}, 4.2 \mathrm{E} 14\right.$ atoms $\left./ \mathrm{cm}^{2}\right)$, (b) ${ }^{51} \mathrm{~V}\left(150 \mathrm{keV}, 1 \mathrm{E} 14\right.$ atoms $\left./ \mathrm{cm}^{2}\right)$, and $(\mathrm{c}){ }^{35} \mathrm{Cl}\left(150 \mathrm{keV}, 5 \mathrm{E} 14\right.$ atoms $\left./ \mathrm{cm}^{2}\right)$ [• as implanted, $\bigcirc$ annealed $300{ }^{\circ} \mathrm{C}, \boldsymbol{\Delta} 500^{\circ} \mathrm{C}, \triangle 700{ }^{\circ} \mathrm{C}, \times 900{ }^{\circ} \mathrm{C}$, $\square$ $\left.1100^{\circ} \mathrm{C}\right]$

$500^{\circ} \mathrm{C}$. Diffusion of boron in silicon is first observed for the $700^{\circ} \mathrm{C}$ annealed sample. For the samples annealed at 900 and $1000{ }^{\circ} \mathrm{C}$, diffusion of boron occurs both to the surface and deep into the silicon matrix. The second category of the implanted elements shows almost no diffusion after the anneals. Among the elements investigated here, $\mathrm{K}$ and $\mathrm{Rb}$ have this behavior (see Fig. 2), and Ge, V, and $\mathrm{Cl}$ (Fig. 3) show limited diffusion either deeper into the silicon matrix (Ge and $\mathrm{Cl}$ ) or toward the peak of the implant $(\mathrm{V})$. The third category includes $\mathrm{Be}, \mathrm{Na}$, and $\mathrm{Mg}$ shown in Fig. 4, and $\mathrm{Ti}$ and Mn shown in Fig. 5. These elements tend to diffuse to the surface of single-crystalline Si during the anneals greater than $700^{\circ} \mathrm{C}$. Note that significant Ti diffusion to the surface, attributed to interstitial motion, occurs only at $1100^{\circ} \mathrm{C}$.

The fourth category includes the elements $\mathrm{Fe}, \mathrm{Ca}, \mathrm{Cr}, \mathrm{Zn}$, and Mo, and the results are influenced by the defects introduced by ion implantation. It is well known that the ion implantation process will generate a high density of defects

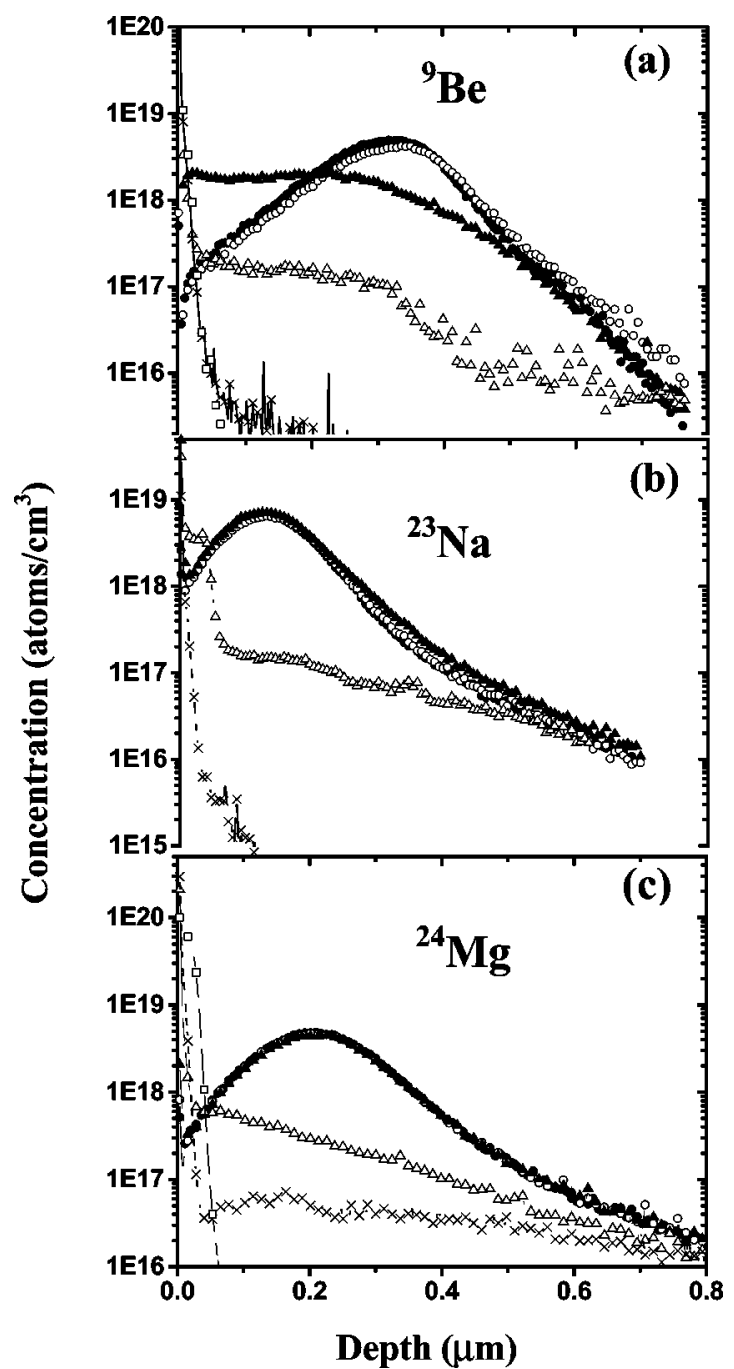

FIG. 4. SIMS depth profiles of (a) ${ }^{9} \mathrm{Be}\left(70 \mathrm{keV}, 1 \mathrm{E} 14\right.$ atoms $\left./ \mathrm{cm}^{2}\right)$, (b) ${ }^{23} \mathrm{Na}$ $\left(70 \mathrm{keV}, 1 \mathrm{E} 14\right.$ atoms $\left./ \mathrm{cm}^{2}\right)$, and $(\mathrm{c}){ }^{24} \mathrm{Mg}\left(120 \mathrm{keV}, 1 \mathrm{E} 14 \mathrm{atoms} / \mathrm{cm}^{2}\right)[\bullet$ as implanted, $\bigcirc$ annealed $300{ }^{\circ} \mathrm{C}, \Delta 500^{\circ} \mathrm{C}, \triangle 700^{\circ} \mathrm{C}, \times 900{ }^{\circ} \mathrm{C}$, $\square 1000^{\circ} \mathrm{C}$ for $\mathrm{Be}, 1100^{\circ} \mathrm{C}$ for $\left.\mathrm{Mg}\right]$.

in $\mathrm{Si}$ and can amorphize the $\mathrm{Si}$ crystal at sufficiently high dose. The interactions of the defects and the diffused atoms and the recrystallization of the amorphous Si layer will have a strong effect on the diffusion behavior of the implanted elements. During the annealing process, precipitation of the supersaturated solid solutions and intermediate compounds may occur at the structural defects. ${ }^{13}$ The SIMS depth profiles of $\mathrm{Fe}$ in the as-implanted and annealed samples, shown in Fig. 6(a), indicate that the implanted $\mathrm{Fe}$ atoms in silicon tend to move to the silicon surface during the annealing process. The diffusion of $\mathrm{Fe}$ starts for the sample annealed at $500{ }^{\circ} \mathrm{C}$ and concentration peaks have been formed at the surface and at $0.13 \mu \mathrm{m}$, but the distribution at depths exceeding $0.13 \mu \mathrm{m}$ was not affected. As the annealing temperature was increased to $900^{\circ} \mathrm{C}$, the implanted $\mathrm{Fe}$ atoms diffuse to the silicon surface and form a concentration peak at about 0.02 $\mu \mathrm{m}$. At this annealing temperature the deeper concentration peak has disappeared. Diffusion of the implanted $\mathrm{Cr}$ toward the surface of silicon starts at $500^{\circ} \mathrm{C}$ [see Fig. 6(b)], similar 


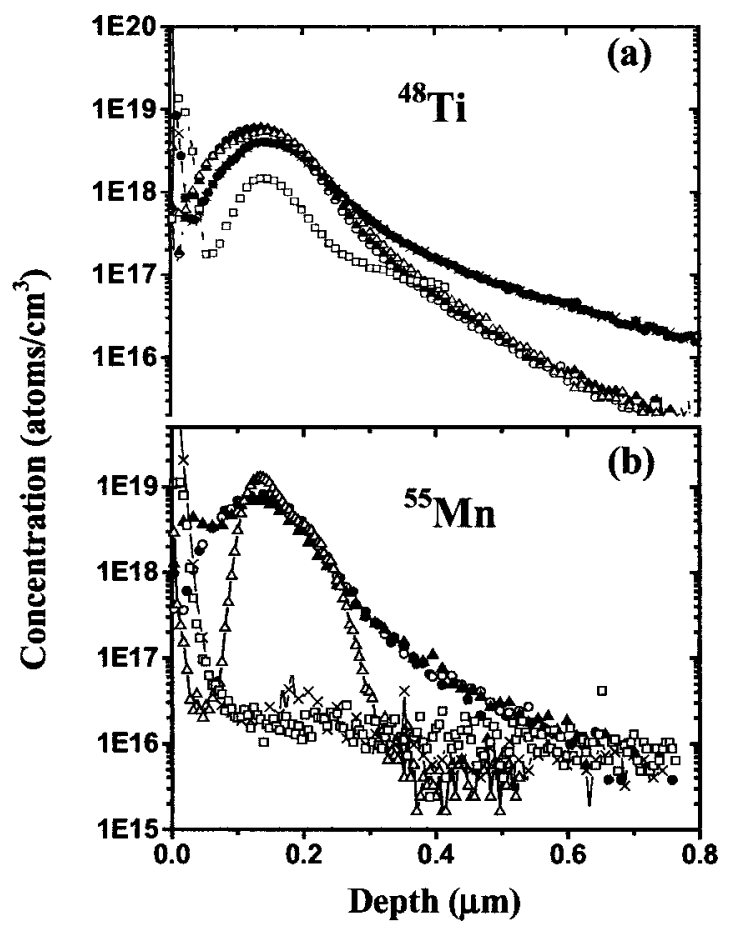

FIG. 5. SIMS depth profiles of (a) ${ }^{48} \mathrm{Ti}\left(150 \mathrm{keV}, 1 \mathrm{E} 14\right.$ atoms $\left./ \mathrm{cm}^{2}\right)$, and (b) ${ }^{55} \mathrm{Mn}\left(150 \mathrm{keV}, 1 \mathrm{E} 14\right.$ atoms $\left./ \mathrm{cm}^{2}\right)\left[\bullet\right.$ as implanted, $\bigcirc$ annealed $300{ }^{\circ} \mathrm{C}$, $\left.\triangle 500{ }^{\circ} \mathrm{C}, \triangle 700{ }^{\circ} \mathrm{C}, \times 900{ }^{\circ} \mathrm{C}, \square 1100^{\circ} \mathrm{C}\right]$.

to Fe. Two concentration peaks, located at 0.06 and $0.18 \mu \mathrm{m}$, have been observed for the samples annealed at 500, 700, and $900{ }^{\circ} \mathrm{C}$. Most of the implanted dose remains even after significant diffusion has taken place. For example, at $500{ }^{\circ} \mathrm{C}$, $90 \%$ of the $\mathrm{Cr}$ implanted dose is present, with 5\% in the 0.18 $\mu \mathrm{m}$ peak. Notice that the implanted $\mathrm{Cr}$ atoms at depths exceeding $0.18 \mu \mathrm{m}$ are only slightly affected by the 700 and $900^{\circ} \mathrm{C}$ anneals. When the annealing temperature was increased to $1100^{\circ} \mathrm{C}$, all the implanted $\mathrm{Cr}$ atoms diffuse to the surface. Figure 6(c) shows that implanted Mo diffuses to the surface of silicon in a manner similar to $\mathrm{Fe}$ and $\mathrm{Cr}$, but with different peak locations. This is in agreement with recent work. ${ }^{14}$

Figure 7(a) presents the SIMS depth profiles of $\mathrm{Zn}$ in the as-implanted and the annealed samples, showing that appreciable diffusion of $\mathrm{Zn}$ into silicon occurs at $300^{\circ} \mathrm{C}$. Concentration peaks just below the surface and at $0.28 \mu \mathrm{m}$ have been formed for the samples annealed at 500 or $700^{\circ} \mathrm{C}$. If the annealing temperature is higher than $900^{\circ} \mathrm{C}$, the implanted $\mathrm{Zn}$ atoms diffuse to the surface of the silicon. Precipitates at the depth of maximum implant damage and the original amorphous-crystalline interface may explain the existence of the two peaks on either side of the as-implanted profile. The diffusion of $\mathrm{Ca}$, shown in Fig. 7(b), to the surface and into the silicon occurs when the samples were annealed above $700^{\circ} \mathrm{C}$ with concentration peaks at 0.1 and $0.15 \mu \mathrm{m}$. Concentration peaks at $0.08,0.17$, and $0.27 \mu \mathrm{m}$ are found for the samples annealed at 900 or $1100^{\circ} \mathrm{C}$.

When three concentration peaks are detected, the first is at the sample surface. The formation of this peak may be explained by the precipitation of solid solutions due to surface

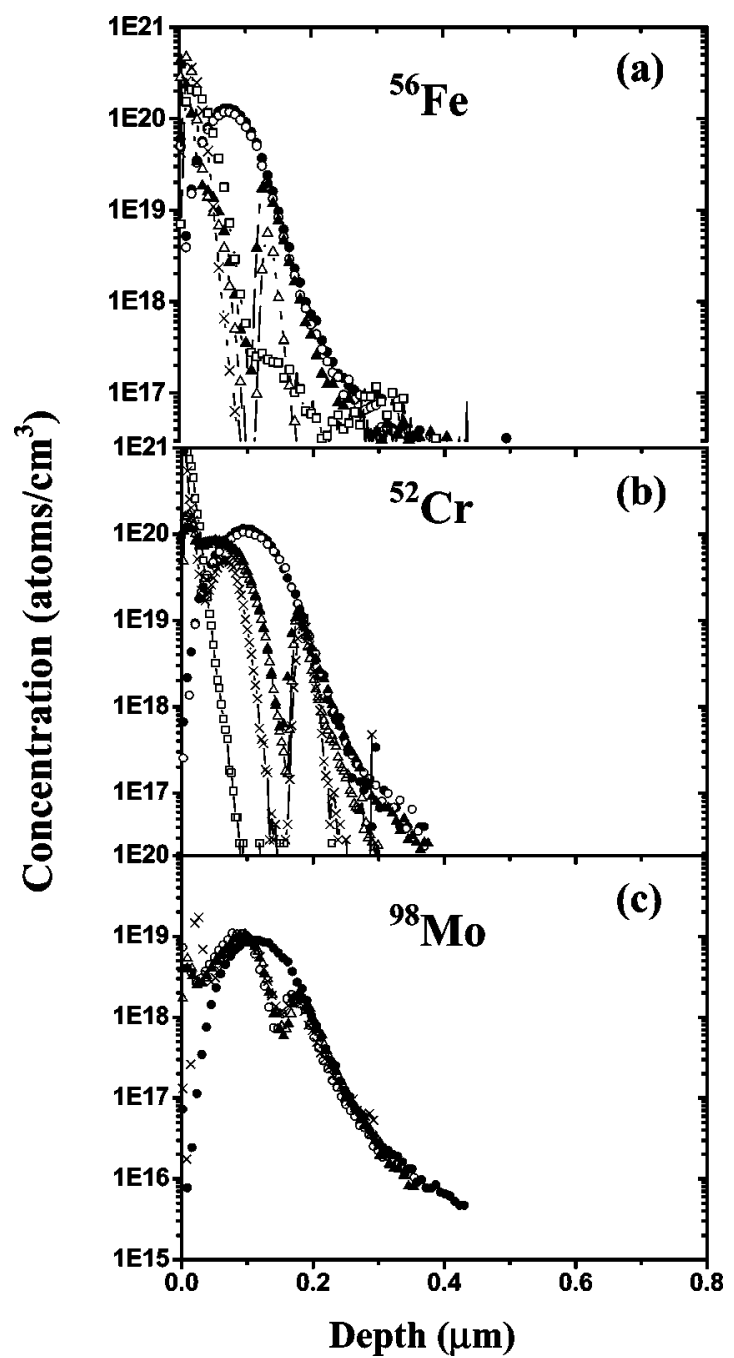

FIG. 6. SIMS depth profiles of (a) ${ }^{56} \mathrm{Fe}\left(100 \mathrm{keV}, 1 \mathrm{E} 15 \mathrm{atoms} / \mathrm{cm}^{2}\right)$, (b) ${ }^{52} \mathrm{Cr}$ $\left(120 \mathrm{keV}, 1.1 \mathrm{E} 15\right.$ atoms $\left./ \mathrm{cm}^{2}\right)$, and (c) ${ }^{98} \mathrm{Mo}\left(180 \mathrm{keV}, 8.8 \mathrm{E} 14\right.$ atoms $\left./ \mathrm{cm}^{2}\right)$ [• as implanted, $\bigcirc$ annealed $300{ }^{\circ} \mathrm{C}, \boldsymbol{\Delta} 500{ }^{\circ} \mathrm{C}, \triangle 700{ }^{\circ} \mathrm{C}, \times 900{ }^{\circ} \mathrm{C}$, $\square 1000^{\circ} \mathrm{C}$ for $\mathrm{Fe}$ and $1100^{\circ} \mathrm{C}$ for $\mathrm{Cr}$ and $\mathrm{Mo}$.

defects formed as a result of ion implantation. The second peak occurs at a depth before the projected range, which is the most probable penetration depth for the implant. For example, the projected range for the $\mathrm{Cr}$ ion implant is 0.104 $\mu \mathrm{m}^{15}$ and the second peak occurs at $0.06 \mu \mathrm{m}$. This concentration peak could be due to the formation of compounds and solid solutions. The third peak is deeper than the projected range and is related to end of range implantation defects and, when the dose is sufficiently high, the interface between amorphous and damaged silicon.

$\mathrm{Ni}$ in silicon represents the fifth diffusion category. Diffusion of $\mathrm{Ni}$ to both the surface and the silicon substrate occurs at $300^{\circ} \mathrm{C}$ (see Fig. 8). Nickel has a uniform distribution to $0.2 \mu \mathrm{m}$ followed by one concentration peak. At $500^{\circ} \mathrm{C}$, two concentration peaks are observed. Cross sectional transmission electron microscopy characterization confirms the precipitation of nickel and the recrystallization of amorphous silicon underneath the surface during the annealing process at high temperatures. 


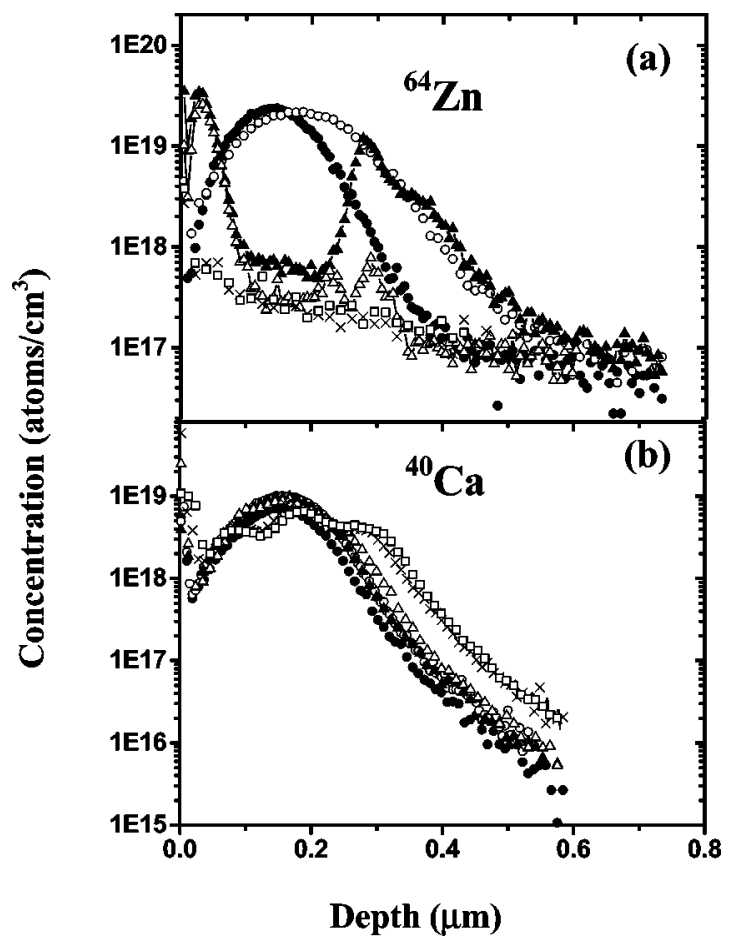

FIG. 7. SIMS depth profiles of (a) ${ }^{64} \mathrm{Zn}\left(180 \mathrm{keV}, 3.3 \mathrm{E} 14\right.$ atoms $\left./ \mathrm{cm}^{2}\right)$ and (b) ${ }^{40} \mathrm{Ca}\left(150 \mathrm{keV}, 1 \mathrm{E} 14\right.$ atoms $\left./ \mathrm{cm}^{2}\right)\left[\bullet\right.$ as implanted, $\bigcirc$ annealed $300{ }^{\circ} \mathrm{C}, \boldsymbol{\Delta}$ $500{ }^{\circ} \mathrm{C}, \triangle 700^{\circ} \mathrm{C}, \times 900^{\circ} \mathrm{C}, \square 1000^{\circ} \mathrm{C}$ for $\mathrm{Zn}, 1100^{\circ} \mathrm{C}$ for $\left.\mathrm{Ca}\right]$.

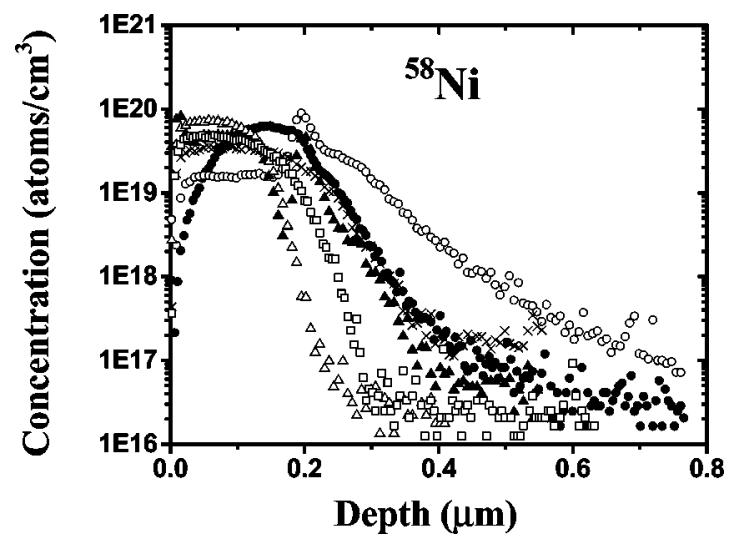

FIG. 8. SIMS depth profiles of ${ }^{58} \mathrm{Ni}\left(160 \mathrm{keV}, 1 \mathrm{E} 14\right.$ atoms $\left./ \mathrm{cm}^{2}\right)[\bullet$ as implanted, $\bigcirc$ annealed $\left.300{ }^{\circ} \mathrm{C}, \boldsymbol{\Delta} 500{ }^{\circ} \mathrm{C}, \triangle 700{ }^{\circ} \mathrm{C}, \times 900{ }^{\circ} \mathrm{C}, \square 1000^{\circ} \mathrm{C}\right]$

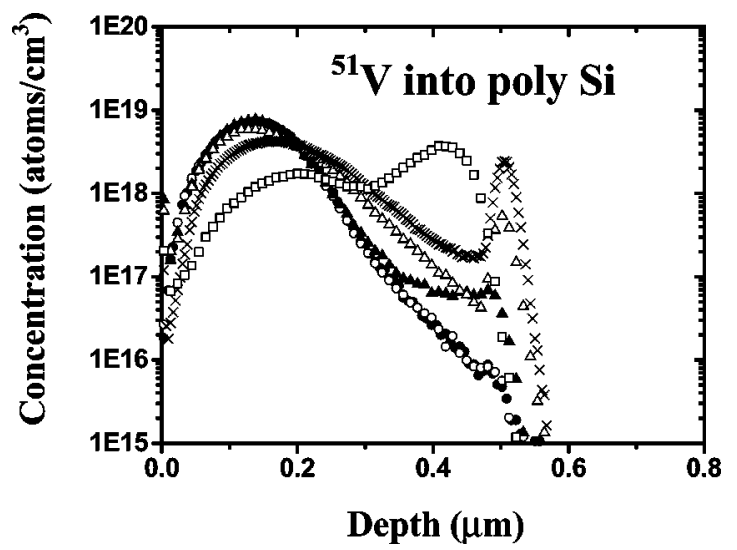

FIG. 9. SIMS depth profiles of ${ }^{51} \mathrm{~V}\left(150 \mathrm{keV}, 1 \mathrm{E} 14\right.$ atoms $\left./ \mathrm{cm}^{2}\right)$ in $0.5 \mu \mathrm{m}$ layer polycrystalline $\mathrm{Si}\left[\bullet\right.$ as implanted, $\bigcirc$ annealed $300^{\circ} \mathrm{C}, \boldsymbol{\Delta} 500^{\circ} \mathrm{C}, \triangle$ $\left.700{ }^{\circ} \mathrm{C}, \times 900{ }^{\circ} \mathrm{C}, \square 1000^{\circ} \mathrm{C}\right]$.
The mechanism of impurity diffusion in polycrystalline silicon can be quite different from that in single-crystalline silicon. A separate category of diffusion is represented by $\mathrm{V}$ in polycrystalline silicon. Figure 9 shows the distribution of $\mathrm{V}$ with increasing temperature becomes more concentrated at the interface of the $0.5-\mu \mathrm{m}$-thick polycrystalline silicon film and the silicon substrate. In contrast to crystalline $\mathrm{Si}$, diffusion of $\mathrm{V}$ in polycrystalline silicon starts at $500{ }^{\circ} \mathrm{C}$ and, instead of moving to the surface, the implanted $\mathrm{V}$ atoms tend to diffuse to the interface between the polycrystalline silicon and the silicon substrate.

\section{SUMMARY}

The diffusion properties of the elements studied can be separated into several categories. For $\mathrm{Cl}, \mathrm{K}, \mathrm{V}, \mathrm{Ge}$, and $\mathrm{Rb}$, very little diffusion has been identified from the SIMS depth profiles. Fast diffusion to the Si surface occurs for $\mathrm{Be}, \mathrm{Na}$, $\mathrm{Mg}, \mathrm{Ti}$, and $\mathrm{Mn}$ if the annealing temperature is above $500^{\circ} \mathrm{C}$. Fe, $\mathrm{Ca}, \mathrm{Cr}, \mathrm{Zn}$, and Mo show a multi-peaked structure after anneal as low as $500{ }^{\circ} \mathrm{C}$. Ni indicates that it may react with $\mathrm{Si}$ and form a layer of silicide in the near-surface region. Finally, the diffusion behavior of $\mathrm{V}$ in polycrystalline $\mathrm{Si}$ is faster than in single crystalline Si. Diffusion measurements for other elements in $\mathrm{Si}$ and a study of the effect of implantation dose are in progress.

\section{ACKNOWLEDGMENTS}

The authors would like to thank the other members of the graduate class who participated in this project: B. Prenitzer, B. Kempshall, T. Kimble, B. Surdik, S. Schwarz, S. Skulkarni, C. Urbanik, E. Houge, A. Hussain, and N. Ravikar. The authors acknowledge the technical and financial support from UCF/Cirent Semiconductor Materials Characterization Facility (MCF) and the Advanced Materials Processing and Analysis Center (AMPAC) at the University of Central Florida. The authors also would like to thank R. Irwin, J. Benton, and H. Gossman for valuable discussions, and Zia Ur Rahman, Jay Bieber, and Kirk Scammon for their assistance.

Presented at the 46th International AVS Symposium, Seattle, WA, 25-29 October 1999.

${ }^{1}$ R. N. Hall and J. H. Racette, J. Appl. Phys. 35, 379 (1964).

${ }^{2}$ B. L. Sharma, Diffusion in Semiconductors (Trans. Tech., ClausthalZellerfeld, Germany, 1970).

${ }^{3}$ A. F. W. Willoughby, Rep. Prog. Phys. 41, 1665 (1978).

${ }^{4}$ D. L. Kendall and D. B. DeVries, in Semiconductor Silicon, edited by R. R. Haberect and E. L. Kern (Electrochemical Society, New York, 1969), p. 414.

${ }^{5}$ F. H. Eisen, Proceedings of the First International Conference on Ion Implantation (Gordon and Breach, New York, 1971).

${ }^{6}$ J. C. North and W. M. Gibson, Appl. Phys. Lett. 16, 126 (1970); J. E. Westmoreland, J. W. Mayer, F. H. Eisen, and B. Welch, ibid, 15, 308 (1969).

${ }^{7}$ F. N. Schwettmann, Appl. Phys. Lett. 22, 570 (1973). J. F. Gibbons, ibid. 23, 49 (1973). H. Shibayama, H. Masaki, and H. Hashimoto, ibid. 27, 230 (1975).

${ }^{8}$ L. J. Eriksson, J. A. Davis, J. Denhartog, J. W. Mayer, O. J. Marsh, and R. Markarious, Appl. Phys. Lett. 10, 323 (1967).

${ }^{9}$ I. M. Mackintosh, J. Electrochem. Soc. 109, 392 (1962). 
${ }^{10}$ M. V. Rao, N. R. Keshavarznia, D. S. Simons, P. M. Amirtharaj, P. E. Thompson, T. Y. Chang, and J. M. Kuo, J. Appl. Phys. 65, 481 (1989).

${ }^{11}$ J. Vellanki, R. K. Nadella, M. V. Rao, O. W. Holland, D. S. Simons, and P. H. Chi, J. Appl. Phys. 73, 1126 (1993).

${ }^{12}$ M. Meuris, P. D. E. Bisschop, J. F. Leeclair, and W. Vandervorst, Surf. Interface Anal. 14, 739 (1989).
${ }^{13}$ S. M. Gulwadi, M. V. Rao, A. K. Berry, D. S. Simons, P. H. Chi, and H. B. Dietrich, J. Appl. Phys. 69, 4222 (1991).

${ }^{14}$ J. L. Benton, D. C. Jacobson, J. A. Johnson, T. Boone, D. J. Eaglesham, F. A. Stevie, and J. Becerro, J. Electrochem. Soc. 146, 1929 (1999).

${ }^{15}$ Simulation using Transport of Ions in Matter, J. F. Ziegler, www.research.ibm.com/ionbeams 